\title{
The Streptococci of Group D; the Serological Grouping of Streptococcus bovis and Observations on Serologically Refractory Group D Strains
}

\author{
By P. M. FRANCES SHATTOCK \\ National Institute for Research in Dairying, University of Reading
}

SUMMARY: The concentration of the group-specific substance in hydrochloric acid extracts by precipitation with ethanol has facilitated the serological identification of Streptococcus bovis and certain other serologically refractory streptococci as members of group D. The notorious difficulty of preparing potent group sera for Str. bovis was overcome by immunizing rabbits with organisms shaken with an abrasive in a magnetic vibrating machine. The relationship of Str. bovis to certain other streptococci and the chemical nature of the specific substance of group D are discussed.

In a serological grouping of haemolytic streptococci from various sources Lancefield (1933) placed in group D a small collection of streptococci isolated from cheese, and Sherman (1938) identified them by biochemical characters as Streptococcus zymogenes. Although Lancefield's classification was originally confined to haemolytic members of the genus, it soon became evident that many non-haemolytic streptococci had group-specific substances in common with haemolytic varieties.

It has been established that the intestinal streptococci, Str. faecalis and its variants zymogenes and liquefaciens, and also Str. durans fall into group D (Sherman, 1938; Graham \& Bartley, 1939; Shattock \& Mattick, 1943; Shattock, 1945).

On the other hand, Str. bovis, a Streptococcus conspicuous in cow-dung and common in milk, has proved difficult to place serologically, although biochemically it is a well-defined species. Raffinose-fermenting streptococci were early recognized as characteristic of the bovine intestine, and Orla-Jensen (1919) introduced the specific name, Str. bovis, on the basis of fermentation tests. The studies of Ayres \& Mudge (1923) on streptococci from bovine mouths and intestines and of Sherman \& Stark (1931) on streptococci growing at high temperatures have provided valuable additional information on this species.

Sherman \& Stark (1931) ascribed to Str. bovis the following characteristics: blood not haemolyzed; litmus milk not reduced before curdling; growth at $45^{\circ}$ but not at 10 or $50^{\circ}$; arabinose, glucose, maltose, lactose, sucrose, raffinose, starch and salicin, and sometimes mannitol and inulin fermented, but glycerol not; ammonia not produced from peptone. Sherman (1938) also observed that Str. bovis does not grow in the presence of $6.5 \% \mathrm{NaCl}$ or $0.1 \%$ methylene blue or at $\mathrm{pH} \mathrm{9 \cdot 6}$. Although Sherman (1937) recorded that Str. bovis survived $60^{\circ}$ for 30 min., strains isolated in this laboratory and tested by the technique described here have consistently failed to pass this test although they withstand $60^{\circ}$ for $15 \mathrm{~min}$. (Shattock \& Mattick, 1943).

Str. bovis has many of the characteristics of group D streptococci, but 
nevertheless is readily distinguished biochemically from Str. faecalis and its variants, and some workers have preferred to separate it from the Enterococcus group. It has been reported (Sherman, 1938; Shattock, 1944) that whereas many strains of Str. bovis give negative or equivocal results with the usual Lancefield technique, about $50 \%$ react elearly with group $D$ sera. In a preliminary note Shattock (1948), on serological grounds, assigned Str. bovis to group D, and experimental details establishing the serological identity of Str. bovis are presented here.

In addition to Str. bovis, streptococci are frequently encountered having cultural reactions similar to, and sometimes identical with, the species within group D, but which fail to react with potent group $\mathbf{D}$ sera. For some years such equivocal strains have been collected from a variety of sources. The serological grouping of these strains is also dealt with in this paper.

\section{MATERIALS AND METHODS}

\section{Biochemical and cultural methods}

Haemolysis. Brown's (1919) technique was followed using, instead of a veal infusion base for the horse-blood plates, a nutrient agar consisting of $2 \%$ agar, $1 \%$ Evans's peptone, 1\% Lemco and 0.5\% NaCl.

Reducing properties. Complete or almost complete reduction of litmus milk in $24 \mathrm{hr}$. at $37^{\circ}$ was recorded as 'strong reduction'.

Gelatin liquefaction. Stab cultures were incubated at $\mathbf{2 2}^{\circ}$ and read after 14 days.

Carbohydrate fermentations. Peptone water containing $0.5 \%$ of the test sugars, added after sterilization, with litmus as indicator, were inoculated with 1 loopful $\left(4.0 \mathrm{~mm}\right.$.) of an $18 \mathrm{hr}$. broth culture, and incubated at $37^{\circ}$. Results were read after 5 days' incubation.

Growth at $45^{\circ}$. Tubes of glucose $(1 \%)$ Lemco broth seeded with 2 loopfuls $\left(4.0 \mathrm{~mm}\right.$.) of an $18 \mathrm{hr}$. culture were incubated in a water-bath at $45 \pm 0 \cdot 1^{\circ}$. Tubes were examined for growth after $24 \mathrm{hr}$.

Growth at $\mathrm{pH} 9 \cdot 6$. The buffered liquid medium described by Shattock \& Hirsch (1947) was used.

Survival at $60^{\circ}$ for $30 \mathrm{~min}$. Two loopfuls $(4.0 \mathrm{~mm}$.) of an $18 \mathrm{hr}$. culture were inoculated into tubes of glucose $(1 \%)$ Lemco broth held in a water-bath at $60 \pm 0 \cdot 10^{\circ}$ for $30 \mathrm{~min}$., cooled immediately, incubated at $37^{\circ}$ for $24 \mathrm{hr}$. and examined for growth.

\section{Serological methods}

Routine preparation of antisera for group $D$. The preparation of potent sera for group $\mathbf{D}$ is notoriously troublesome. As with other Lancefield groups the choice of immunizing strain is important. Over a period of years many strains of all species within group $\mathbf{D}$ have been used for this purpose, and, though group sera have been prepared successfully from all the established species and variants within the group, a strain of Str. durans (98D) kindly supplied by Prof. Sherman has so far produced the most consistently potent serum. Though 
it is possible to produce a group $\mathbf{D}$ serum with formalin or heat-killed organisms a more reliable method is that of Shattock \& Mattick (1943) using acetoneextracted ground organisms. The $24 \mathrm{hr}$. growth from 4-5 l. of glucose Lemco broth, incubated at $37^{\circ}$, is centrifuged, the organisms resuspended in approximately $100 \mathrm{ml}$. acetone and extracted at room temperature for $4-5 \mathrm{hr}$. in a mechanical shaker revolving approximately 70 times/min. The acetone is discarded and extraction once repeated. The extracted organisms are dried in vacuo over $\mathrm{P}_{2} \mathrm{O}_{5}$ and finally ground in a ball mill until microscopic examination shows that very few intact cocci remain. The resulting powder can be stored indefinitely in a vacuum desiccator over $\mathrm{P}_{2} \mathrm{O}_{5}$ at room temperature. One batch of powder stored for $\mathbf{3}$ years still induced potent group D sera, and a good group $\mathbf{N}$ serum was obtained with a similar preparation 9 years old.

For injection the powder is suspended in $\mathbf{0 . 8 5} \% \mathrm{NaCl}$ to give an opacity equivalent to Brown's tube no. 7 (Burroughs Wellcome and Co., Red Lion Square, London, W.C. 1). Rabbits are injected every 3-4 days starting with $0.25,0.5$ and then $1.0 \mathrm{ml}$. doses. It is well known that the individual rabbit response varies enormously and a potent specific group serum may be produced after 6-8 injections, but more often it is necessary to give two or three series of injections before a satisfactory serum is obtained. A rabbit which responds well is invaluable and may be rested, given one or two boosting injections and bled at intervals until eventually non-specific antibodies make their appearance. One rabbit was a source of potent and specific group D serum for 3 years. Specificity and group antibody potency are checked and sera are stored in the cold without preservative.

Although this technique has been very satisfactory for the routine production of group D sera and has been used successfully with Str. faecalis and its variants, and with Str. durans, it has not proved suitable with Str. bovis. It was thought that the comparatively long grinding in a ball mill might destroy the group substance, apparently present only in small amounts in Str. bovis, and other methods of rupturing the organisms were accordingly tried.

Preparation of group sera for Str. bovis. Strains of Str. bovis were grown for $24 \mathrm{hr}$. at $37^{\circ}$ in glucose Lemco broth, the organisms removed by centrifuging and resuspended in $\mathbf{0 . 8 5} \% \mathrm{NaCl}$ to give an opacity equivalent to Brown's tube no. 10. Ten $\mathrm{ml}$. of the suspension were then transferred to a cylindrical glass vessel of $20 \mathrm{ml}$. capacity containing $0 \cdot 3-0.5 \mathrm{~g}$. washed and sterilized carborundum (grade 100). The vessel was shaken in a magnetic shaker (Mickle, 1948) having a frequency of $50 / \mathrm{sec}$. and an amplitude of $c . \frac{1}{2}$ in. Suspensions of the three strains of Str. bovis and of Str. durans $98 \mathrm{D}$ became virtually sterile when shaken in this way for $90 \mathrm{~min}$.

Sera were first prepared by giving, at 3-4-day intervals, four graded injections of formalin-killed suspensions followed by three $1 \mathrm{ml}$. doses of organisms shaken with carborundum for $60 \mathrm{~min}$. and freshly prepared for each injection. In a second experiment with the same strains of Str. bovis the preliminary injections with formalin-killed suspensions were omitted. Potent group sera were produced by giving, at intervals of 3-4 days, four $1 \mathrm{ml}$. doses of organisms shaken with carborundum for $90 \mathrm{~min}$. and freshly prepared for each inocula- 
tion. In both experiments the group D strain, Str. durans $98 \mathrm{D}$, used in this laboratory for the routine production of group $\mathrm{D}$ sera, was included as a control and by both treatments potent and specific group D sera were obtained.

Extracts. Of the various methods of extraction tried (Shattock \& Mattick, 1943) Lancefield's (1933) technique gave the most reliable results for group D.

Group D cocci are grown in $50 \mathrm{ml}$. glucose Lemco broth at $37^{\circ}$, preferably for $48 \mathrm{hr}$; t the extra $24 \mathrm{hr}$. incubation results in more potent extracts. The centrifuged organisms are extracted for 10-12 min. in a boiling water-bath with $1.5 \mathrm{ml} .0 .05 \mathrm{~N}-\mathrm{HCl}$ made up in $0.85 \% \mathrm{NaCl}$, and neutralized with little delay; extracts stored overnight in the ice-chest before neutralizing may deteriorate considerably. In our experience the deterioration of the groupspecific substance by storage in weak acid is not a characteristic of other groups; unneutralized $\mathrm{HCl}$ extracts of group $\mathrm{B}$ can be stored at room temperature overnight without losing potency.

For some reason not fully understood, $\mathrm{HCl}$ extracts of group D streptococci are very sensitive to slight differences in their preparation. Different brands of peptone vary greatly in their suitability. With some peptones, though growth is good, extracts are cloudy or opalescent and unsuitable for ring tests. Evans's peptone (Evans Medical Supplies Ltd.) proved the most reliable brand for this work.

Mention has already been made of the difficulty, even with potent group D sera, of grouping many of the streptococci having cultural and biochemical reactions very similar to, or even identical with, the various members of group D. Str. bovis in particular has proved troublesome. The failure of these strains to give potent $\mathrm{HCl}$ extracts is not necessarily associated with weight of growth, and it was thought that these refractory strains might be poor in group substance.

Lancefield (1928), working with group A, separated the protein-type substance from the carbohydrate group substance by precipitation with ethanol and concentrating the group substance in the supernatant fluid. Following this technique with $\mathrm{HCl}$ extracts of typical group D strains, it was unexpectedly found that ethanol precipitated both the type and group substances, while the supernatant apparently contained no serologically precipitable material. Preliminary work indicates that the group-specific substance in these strains is a protein, and if this is confirmed some of the difficulty in dealing with refractory group D strains may be explained. Foley \& Wheeler (1945), in dealing with strains from pathological sources found that of four group $D$ strains of different serological types the group substance was of a protein nature in three and carbohydrate in one, but they did not discuss this anomalous observation.

The precipitation of the group substance from $\mathbf{H C l}$ extracts by ethanol provided a routine method for dealing with refractory strains. If $\mathrm{HCl}$ (Lancefield) extracts do not react with group $\mathbf{D}$ sera, the extracts after the addition of 4 vol. ethanol are allowed to stand overnight in the ice-chest (a small crystal of sodium acetate facilitates precipitation). The resulting precipitate from $1.5 \mathrm{ml}$. of $\mathrm{HCl}$ extract is well mixed with $0.3-0.5 \mathrm{ml}$. of $0.85 \%$ saline, and the 
small quantity of insoluble material removed by centrifuging. The clear supernatant (fraction A) contains the concentrated group substance and may be used for the precipitin test. The specificity of fraction A prepared from many strains of group $\mathbf{D}$ has been checked against sera for other groups, and similar ethanol precipitates from strains of other groups (including group $\mathbf{N}$ and Str. thermophilus) consistently failed to react with group D sera.

Precipitin test. A small quantity of serum is introduced with a Pasteur pipette into a tube with an internal diameter of $3 \mathrm{~mm}$., the extract is layered on top and allowed to stand at room temperature. The junction of the two fluids is examined for ring formation against a standard diffused light. With a very potent serum the reaction takes place in a few seconds, but 10-15 min. may be required with a weak serum. Each batch of serum when harvested is tested for approximate reaction time against a selection of group $\mathbf{D}$ strains of different serological and biochemical types, and the reaction period for unknown strains is arranged accordingly. A serum giving a well-defined ring within $5 \mathrm{~min}$. is satisfactory.

Absorption tests. Organisms for absorption are grown in glucose Lemco broth at $37^{\circ}$ for $48 \mathrm{hr}$. The cells are centrifuged off, washed once in $0 \cdot 85 \% \mathrm{NaCl}$, resuspended in saline to give a density equivalent to 10 times Brown's opacity tube no. 10, killed by heating at $60^{\circ}$ for $60 \mathrm{~min}$. and then packed by centrifuging. When suspended in undiluted antiserum the absorbing suspension has 50 times the opacity of Brown's tube no. 10. Absorption was carried out at $37^{\circ}$ for $1 \mathrm{hr}$., followed by refrigeration overnight before removing the cocci by centrifuging. The absorbed sera are tested for precipitins by the ring test and the results checked by Lancefield's (1933) technique with various dilutions of extract, reading the reaction after $2 \mathrm{hr}$. at $37^{\circ}$ and after standing in the ice-chest overnight.

\section{RESULTS}

The serological grouping of Streptococcus bovis

Reference has been made to difficulties in classifying Str. bovis. Although some affinity with group $\mathrm{D}$ streptococci has been recognized, $\mathrm{HCl}$ extracts of typical strains of Str. bovis have often given anomalous results with sera for group D. By concentrating the group substance in fraction $\mathbf{A}$, refractory strains of Str. bovis will react with a group D serum. At least forty-five strains having the biochemical characteristics of Str. bovis were examined by this technique, and none failed to give a clear-cut specific reaction with group $\mathbf{D}$ sera.

Group-specific sera were prepared against two strains of Str. bovis, 'Pearl 11' and 'Rosalie 20', isolated from cow-dung and having the typical species characteristics. That sera produced from these strains of Str. bovis did possess group and not merely type antibodies was demonstrated by their precipitation with extracts of twelve heterologous group D strains comprising at least three distinct serological types within group D. They were: Str. faecalis, two strains; var. zymogenes, four strains; var. liquefaciens, two strains; Str. durans, two strains; and Str. bovis, two strains. The specificity of the sera was established 
by testing against $\mathrm{HCl}$ extracts of representatives of each of the Lancefield groups $\mathbf{A}-\mathbf{N}$ and with a strain of a Staphylococcus rich in the non-specific nucleoprotein fraction common to all streptococci and staphylococci (Lancefield, 1925).

\section{Reciprocal absorption tests}

The serological identity of Str. bovis with group D was confirmed by reciprocal absorption tests with the sera for Str. bovis and sera prepared from the strain of Str. durans used in this laboratory for the routine production of group $\mathbf{D}$ sera.

Absorption of a group D serum with Str. bovis. A potent and specific group D serum prepared against Str. durans 98D was absorbed with three strains of Str. bovis: 'Pearl 11', 'Rosalie 20' and 'Campion 11'. The absorbed sera were tested for group D antibodies with an extract of Str. faecalis ' $\mathrm{C}$ and G', which was chosen as being of a different serological type from the group $D$ strain $98 \mathrm{D}$ and for this reason unlikely to confuse the issue by reacting with type antibodies.

'Table 1. Absorption of group $D$ antibodies by Streptococcus bovis

$\begin{array}{lcccc}\text { Extract } & \text { Unabsorbed } & \overbrace{\text { 'Pearl 11' }}^{\text {Group D serum }} & \text { 'Rosalie 20' 'Campion 11 } \\ \text { Str. faecalis 'C and G' } & + & - & - & - \\ \text { Str. bovis 'Pearl 11' } & + & - & - & - \\ \text { Str. bovis 'Rosalie 20' } & + & - & - & - \\ \text { Str. bovis 'Campion 11' } & + & - & - & -\end{array}$

Precipitation was observed as ring tests and confirmed by incubation of various concentrations of extract against the same volume of serum (Lancefield, 1933). Results summarized in Table 1 show that group $D$ antibodies were completely absorbed by all three strains of Str. bovis. In a parallel control test a group B streptococcus failed to absorb any antibodies.

Absorption of Str. bovis sera with group D streptococci. Sera prepared against 'Pearl 11' and 'Rosalie 20' were absorbed with Str. faecalis 775 and Str. durans $98 \mathrm{D}$, and the absorbed sera tested with an extract of the group D strain Str. faecalis var. zymogenes 'Black'. Again there was complete absorption of group antibodies (Table 2). A control absorption test with a group B Streptococcus was negative.

Table 2. Absorption of group sera for Streptococcus bovis by group $D$ streptococci

\begin{tabular}{|c|c|c|c|c|c|c|}
\hline \multirow[b]{3}{*}{ Extract } & \multicolumn{3}{|c|}{ Serum 'Pearl 11' } & \multicolumn{3}{|c|}{ Serum 'Rosalie 20' } \\
\hline & \multirow[b]{2}{*}{ Unabsorbed } & \multicolumn{2}{|c|}{ Absorbed } & \multirow[b]{2}{*}{ Unabsorbed } & \multicolumn{2}{|c|}{ Absorbed } \\
\hline & & 775 & $98 \mathrm{D}$ & & 775 & 981 \\
\hline $\begin{array}{l}\text { Str. faecalis var. } \\
\text { zymogenes 'Black' }\end{array}$ & + & - & - & + & - & - \\
\hline Str. faecalis 775 & + & $-\cdot$ & - & + & - & - \\
\hline Str, durans $98 \mathrm{D}$ & + & - & - & + & - & - \\
\hline
\end{tabular}




\section{Serological experiments with refractory group $D$ streptococci}

Reference has been made to streptococci resembling, biochemically, the recognized species and variants within group $\mathbf{D}$ but which fail to react with potent group D sera by the usual Lancefield technique. The technique used to make potent fraction A extracts of Str. bovis was applied to a collection of these aberrant strains isolated from human faeces, cow-dung, gut of fly, water, cheese and dried egg.

Table 3. The physiological characters of group $D$ strains reacting with concentrated extracts ( fraction $A$ ), but not with crude $\mathrm{HCl}$ extracts

Species or variants

Str. faecalis

Str. faecalis variants

Str. faecalis var. liquefaciens

Str. faecalis var. zymogenes

Str, durans

Str. bovis

Unclassified

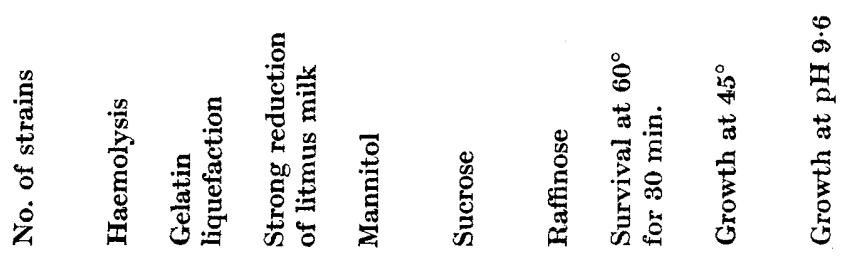

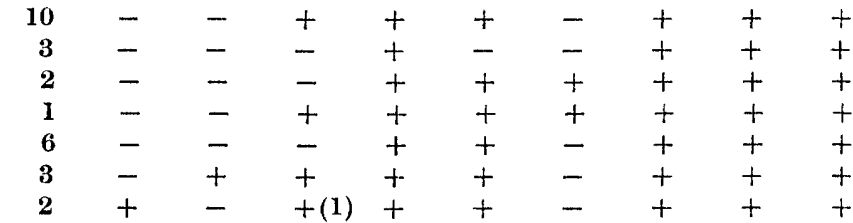

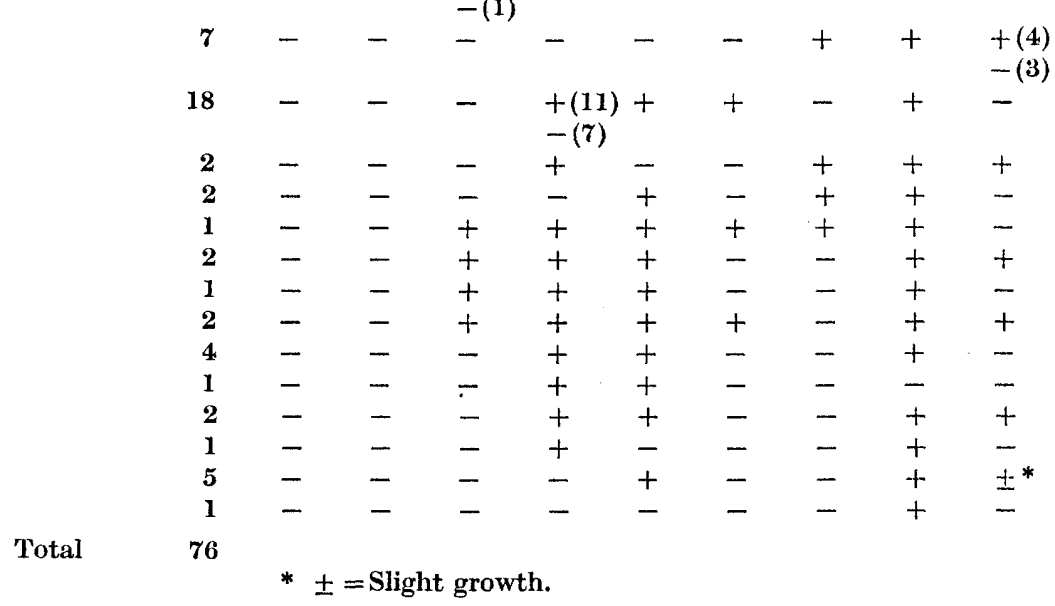

Table 3 gives the cultural characters of seventy-six such strains which consistently failed to react with potent group D sera by the usual Lancefield technique but which all clearly precipitated when the group substance was concentrated (fraction A).

Whereas specific names can be assigned to fifty-two of these strains the remaining twenty-four, in accordance with opinions previously expressed (Shattock, 1945), are listed as unclassified. It is of interest that other strepto- 
cocci with the cultural characters of the unclassified strains in Table 3, but which could be readily grouped without recourse to fraction $\mathrm{A}$, have been frequently encountered. This lends further support to the serological assignment of such strains to group D.

Without a large-scale statistical survey it is not possible to assess the prevalence of group D strains with an apparent deficiency in group substance. The seventy-six strains described here were collected over a period of years and retained because they could not be grouped by the accepted serological

Table 4. Numbers of group $D$ strains from infant faeces reacting as fraction $A$ only, compared with those reacting as crude $\mathrm{HCl}$ extracts

\begin{tabular}{|c|c|c|c|}
\hline \multirow[b]{2}{*}{ Species or variants } & \multirow{2}{*}{$\begin{array}{l}\text { No. of strains } \\
\text { tested }\end{array}$} & \multicolumn{2}{|c|}{$\begin{array}{c}\text { No. of strains reacting with } \\
\text { group D sera }\end{array}$} \\
\hline & & $\begin{array}{l}\text { As } \mathrm{HCl} \\
\text { extracts }\end{array}$ & $\begin{array}{l}\text { As fraction } \\
\text { A only }\end{array}$ \\
\hline Str. faecalis & 126 & 118 & 8 \\
\hline Str. faecalis var. liquefaciens & $40^{\circ}$ & 43 & 3 \\
\hline Str. faecalis var. zymogenes & 24 & 22 & 2 \\
\hline Str. durans & 3 & 3 & 0 \\
\hline Str. bovis & 30 & 20 & 10 \\
\hline Unclassified & 31 & 21 & 10 \\
\hline Total & 260 & 227 & 33 \\
\hline Percentage & & $87 \cdot 3$ & $12 \cdot 7$ \\
\hline
\end{tabular}

methods. Some indication of the incidence of such strains among group D streptococci from one source, infant faeces, is given in Table 4, for which I am indebted to Miss M. E. Sharpe of this laboratory. Of 260 strains $12.7 \%$ were grouped only by recourse to fraction A. There were no strains having biochemical properties resembling members of group $\mathbf{D}$ which could not be classified. Some further information on this point is furnished by Mattick \& Shattock (1943). In an investigation on the numbers of group D streptococci occurring in English hard cheese it was found that of seventy-six cultures isolated from Cheddar cheese by a selective technique, and having the biochemical characters of group D streptococci, ten (13\%) failed to precipitate with potent group D sera by the usual Lancefield technique. Four of the aberrant strains were kept and have since given definite reactions with group D sera, using fraction $\mathbf{A}$ as antigen.

\section{DISCUSSION}

In a review of the streptococci, Sherman (1937) placed Str. bovis with Str. salivarius, Str. equinus and Str. thermophilus in what he termed the 'viridans group'. Schottmüller (1903) suggested Str. viridans as a name for streptococci giving zones of green discoloration on blood agar. This property, now known to be due to the production of hydrogen peroxide, is shared by many species of streptococei belonging to various serological groups. The application of the term 'viridans' to a collection which includes a proportion only of the 
hydrogen peroxide forming species and also contains a species, Str. thermophilus, which is inert on blood agar, is unfortunate.

Biochemically Str. salivarius bears a marked resemblance to Str. bovis. However, the fermentation of starch and arabinose by Str. bovis, its higher maximum temperature for growth and its greater tolerance of bile serve to distinguish it from Str. salivarius. It is not proposed to discuss in detail the differentiation of these two species, as it has been fully described by Sherman (1937) and by Sherman, Niven \& Smiley (1943). In addition to biochemical

Table 5. Differentiation of species within group D

\begin{tabular}{|c|c|c|c|c|c|c|c|c|c|}
\hline Species & Haemolysis & $\begin{array}{l}\text { Gelatin } \\
\text { lique- } \\
\text { faction }\end{array}$ & $\begin{array}{l}\text { Strong } \\
\text { reduction } \\
\text { of } \\
\text { litmus } \\
\text { milk }\end{array}$ & Mannitol & Sucrose & Raffinose & $\begin{array}{c}\text { Survival } \\
\text { at } 60^{\circ} \\
\text { for } \\
30 \text { min. }\end{array}$ & $\begin{array}{l}\text { Growth } \\
\text { at } 45^{\circ}\end{array}$ & $\begin{array}{l}\text { Growth } \\
\text { at } \\
\text { pH 9.6 }\end{array}$ \\
\hline Str. faecalis & - & - & + & + & \pm & - & + & + & + \\
\hline $\begin{array}{l}\text { Str. faecalis var. } \\
\text { zymogenes }\end{array}$ & + & \pm & \pm & + & + & - & + & + & + \\
\hline $\begin{array}{l}\text { Str. faecalis var. } \\
\text { liquefaciens }\end{array}$ & - & + & + & + & + & - & + & + & + \\
\hline Str. durans & \pm & - & - & - & - & - & + & \pm & \pm \\
\hline Str. bovis & - & - & - & \pm & + & + & - & + & - \\
\hline
\end{tabular}

studies they prepared type-specific sera for Str. salivarius but were unable to demonstrate any group relationship with group $\mathrm{D}$. It is of interest to note that in this laboratory also no evidence of any serological affinity between Str. salivarius and group D has been obtained. Concentrated extracts prepared from strains of Str. salivarius gave no reactions with potent group D sera.

The preparation of specific group sera from typical strains of Str. bovis unequivocally places it with other intestinal streptococci in group $\mathbf{D}$, though it is clearly a distinct species within the group, being distinguished from the other members by the tests shown in Table $\mathbf{5}$.

Mention must be made of two other species of streptococci which have been erroneously associated with group D.

Str. uberis, an inhabitant of the bovine vagina and occurring frequently in normal milk, is also associated with a form of bovine mastitis which is usually sporadic but which may assume epidemic proportions. Str. uberis has some of the cultural characteristics of group D streptococci, and Smith \& Sherman (1942) have in fact included it in group D. Its serological grouping has, however, not yet been satisfactorily defined, although it is undoubtedly physiologically and antigenically related to group E (Little, 1939; Plastridge \& Williams, 1939). The serological affinity of Str. uberis to members of group E has been confirmed in this laboratory by Jacob (1947). He investigated the physiological and antigenic characters of 123 strains of Str. uberis isolated by various workers and found that though they were closely related to group $\mathbf{E}$ there was no evidence of any relationship with group $\mathbf{D}$. The group-specific substance of Str. uberis was not precipitated from $\mathrm{HCl}$ extracts with ethanol, 
unlike group D streptococci, whilst Fuller's (1938) method of extraction gave better results than did Lancefield's extracts.

Str. thermophilus is another species which has yet to be grouped. Although its high maximum growth temperature of $47-50^{\circ}$ may suggest that it is of intestinal origin there is no evidence in support of this. It is often found in milk and milk products, particularly those that have been pasteurized, but it has not been reported from human or animal sources. Abd-El-Malek \& Gibson (1948), in a study of streptococci from pasteurized milk, grouped Str. bovis and Str. thermophilus together on biochemical grounds and suggested that they were closely allied. The sensitivity of Str. thermophilus to bile, its inability to ferment a large number of carbohydrates, and its characteristic pleomorphic morphology clearly distinguish it from Str. bovis. As yet Str. thermophilus has not been grouped serologically, although typing sera have been prepared in this and other laboratories (Zollikofer \& Janaik, 1944). One fact has been established in this laboratory: it bears no antigenic relationship to group $\mathrm{D}$ nor does it precipitate with sera of any of the groups A to N.

It is appropriate to discuss briefly the present position of group D streptococci in relation to each other, as some confusion of nomenclature is still apparent in recent literature. Evans \& Chinn (1947), in a paper on the 'Enterococci with special reference to their association with human disease', divided their collection of group D streptococci on the basis of cultural tests, susceptibility to two strains of phage, and agglutination tests apparently carried out with unabsorbed sera. They found that the type of haemolysis and liquefaction were unrelated to other characteristics and suggest that their main group of seventeen strains, comprising cultures having the properties of Str. faecalis, Str. faecalis var. liquefaciens and Str. faecalis var. zymogenes, should all be included under the name Str. zymogenes as having prior claim to specific name. Str. zymogenes was originally described as Micrococcus zymogenes by MacCallum $\&$ Hastings (1899), but the study of colonial appearance on blood agar was at that time yet to be introduced, and their admirable description might equally well have applied to Str. faecalis var. liquefaciens, identified by Orla-Jensen (1919) with the Micrococcus casei amari of Freudenreich. It is of interest to note in this connexion that non-haemolytic proteolytic strains have been associated with pathological conditions (e.g. Elser \& Thomas, 1936). The specific name Streptococcus faecalis, introduced and clearly defined by Andrewes \& Horder (1906), has been accepted and its description extended by recognized authorities in more than one field (e.g. Dible, 1921; Sherman, 1938). To discard this well-established name at this stage would merely cause confusion where some order has been established. Although the close relationship of Str. faecalis to the proteolytic and haemolytic enterococci is fully appreciated (Sherman, Stark \& Mauer, 1937), and although it is recognized (Shattock \& Mattick, 1943; Elser \& Thomas, 1936; Sharpe, 1948) that haemolysis, or even proteolysis, is not fundamentally associated with antigenic pattern, no useful purpose would be served at present by discarding the names liquefaciens and zymogenes as varieties of the central type. Information on the type serology of group $D$ is insufficient for practical use at present, but doubtless it is only a question of 
time before a serological division similar to that worked out for group A will enable significant and fundamental distinctions within group $\mathrm{D}$ to be made.

It is acknowledged (Shattock, 1945), and has been demonstrated again in this paper, that there are no clear-cut lines of demarcation between the various species in group $\mathbf{D}$, but certain well-defined members may be identified and Str. bovis has now been added to their ranks (Table 5). If specific names are to retain any significance, aberrant strains should be described as belonging to the serological group and their cultural characters recorded until more precise (e.g. serological typing) information becomes available. In this connexion, particularly where growth under certain specified conditions is observed (e.g. Shattock \& Hirsch, 1947), the necessity of adhering strictly to a uniform technique cannot be emphasized too strongly.

Group $D$ specific substance. The concentration of the group-specific substance by precipitation from $\mathrm{HCl}$ extracts with ethanol not only gives a method of grouping refractory strains but also raises the question of the nature of the specific substance of group $\mathbf{D}$. It has been assumed, apparently by analogy with groups A, B and C (Lancefield, 1940-1; Wilson \& Miles, 1946), that the group-specific substances of the Streptococcus groups $\mathbf{A}-\mathbf{N}$ are all complex carbohydrates. Preliminary work in this laboratory based on crude fractionation and colour tests, however, indicates that the group-specific substance of $\mathrm{D}$ is probably protein. This agrees in part with the work of Foley \& Wheeler (1945), who, as already noted, found that in some group D strains the groupspecific substance was protein. Their finding of a carbohydrate group-specific substance in another strain, however, is not easy to understand. That there should be within the same group so-called group-specific substances of totally different chemical nature seems to conflict with the criterion on which the grouping of the streptococci is based. Whether the substance be protein or carbohydrate is immaterial, but the use of the term 'group-specific' to a bacterial component should imply that it is common to all members of the group. More precise information on the chemical nature of the group-specific fraction of group $\mathbf{D}$ would doubtless help to explain the unusual difficulties encountered in serological studies on this group.

I wish to thank Dr A. T. R. Mattick for his interest in this work, and Mr L. G. Newland for technical assistance.

\section{REFERENCES}

Abd-El-Malek, Y. \& Gibson, T. (1948). Studies in the bacteriology of milk. I. The streptococci of milk. J. Dairy Res. 15, 233.

Andrewes, F. W. \& Horder, T. J. (1906). A study of the streptococci pathogenic for man. Lancet, ii, 708.

Ayers, S. H. \& Mudge, C. S. (1923). Streptococci of faeces and mouth of cows. V. Studies of the streptococci. J. infect. Dis. 33, 156.

Brown, J. H. (1919). The use of blood agar for the study of streptococci. Monogr. no. 9. Rockefeller Inst. med. Res.

Drble, H. (1921). The Enterococcus and the faecal streptococci: their properties and relations. J. Path. Bact. 24, 3 . 
Elser, W. J. \& Thomas, R. A. (1936). Studies of Streptococcus zymogenes. J. Bact. $31,79$.

Evans, A. C. \& Chinn, A. L. (1947). The Enterococci: with special reference to their association with human disease. J. Bact. 54, 495.

Foley, G. E. \& Wheeler, S. M. (1945). Studies on the streptococci ('Enterococci') of Lancefield group D. I. Serologic and biochemical characteristics. Amer. J. Dis. Child. 70, 93.

Fulder, A. T. (1938). The formamide method for the extraction of polysaccharide from haemolytic streptococci. Brit. J. exp. Path. 19, 130.

Graham, N. C. \& Bartley, E. O. (1939). Some observations on the classification of enterococci. J. Hyg., Camb., 39, 538.

$\mathrm{J}_{\mathrm{ACOB}}$, M. M. (1947). Investigations on streptococcal mastitis and the streptococci. II. A serological study of the haemolytic streptococci of group E (Lancefield) and of Streptococcus uberis. Univ. Reading: Thesis.

LANCEFIEID, R. C. (1925). The immunological relationships of Streptococcus viridans and certain of its chemical fractions. II. Serological reactions obtained with antinucleoprotein sera. J. exp. Med. 42, 397.

LANCEFIELd, R. C. (1928). The antigenic complex of Streptococcus haemolyticus. II. Chemical and immunological properties of the protein fractions. $J$. exp. Med. 47, 469.

LANCEFIELD, R. C. (1933). A serological differentiation of human and other groups of haemolytic streptococci. J. exp. Med. 57, 571.

LANCEFIELD, R. C. (1940-1). Specific relationship of cell composition to biological activity of haemolytic streptococci. New York: Harvey Lect. 36, 251.

Litrtue, R. B. (1939). A discussion of the international classification of the streptococei of bovine mastitis. 13 th Ann. Rep. N.Y. St. Ass. Dairy Milk Insp. p. 35.

MacCallum, W. G. \& Hastings, T. W. (1899). A case of acute endocarditis caused by Micrococcus zymogenes (nov.spec.), with a description of the micro-organism. J. exp. Med. 4, 521.

Matrick, A. T. R. \& Shatrock, P. M. F. (1943). Group D streptococci in English hard cheese. Mon. Bull emerg. publ. Hlth Lab. Serv. $2,73$.

Mrckle, H. (1948). Tissue Disintegration. J.R. micr. Soc. 68, 10.

Orla-Jensen, S. (1919). The Lactic Acid Bacteria. Copenhagen.

Plastridge, W. N. \& Williams, L. F. (1939). Serological types of Streptococcus uberis. J. Bact. 28, 352.

SchotTmüller, H. (1903). Die Artunterscheidung der für den Menschen pathogenen Streptokokken durch Blutagar. Münch. med. Wschr. 50, 849, 909.

Sharpe, M. E. (1948). Personal communication.

ShatTock, P. M. F. (1944). The serological typing and grouping of some streptococci of milk and milk products. Proc. Soc. agric. Bact. p. 69.

Shatтock, P. M. F. (1945). Streptococcus durans. Proc. Soc. appl. Bact. p. 18.

Shatтock, P. M. F. (1948). Streptococcus bovis. Nature, Lond., 161, 318.

Shatтock, P. M. F. \& Hirsch, A. (1947). A liquid medium buffered at pH 9.6 for the differentiation of Streptococcus faecalis from Streptococcus lactis. J. Path. Bact. 59,495 .

Shattock, P. M. F. \& Matrick, A. T. R. (1943). The serological grouping of Streptococcus lactis (group N) and its relationship to Streptococcus faecalis. J. Hyg., Camb., 43, 173.

Sherman, J. M. (1937). The streptococci. Bact. Rev. 1, 3.

Sherman, J. M. (1938). The enterococci and related streptococci. J. Bact. 35, 81.

Sherman, J. M., Niven, C. F. \& Sminey, K. L. (1943). Streptococcus salivarius and other non-haemolytic streptococci of the human throat. J. Bact. 45, 249.

Sherman, J. M. \& Stark, P. (1931). Streptococei which grow at high temperatures. J. Bact. 22, 275 . 
Sherman, J. M. \& Stark, P. (1934). The differentiation of Streptococcus lactis from Streptococcus faecalis. J. Dairy Sci. 17, 525.

Sherman, J. M., Stark, P. \& MaUer, J. C. (1937). Streptococcus zymogenes. J. Bact. $33,483$.

Smith, P. A. \& Sherman, J. M. (1942). The lactic acid fermentation of streptococci. J. Bact. 43, 725.

Wilson, G. S. \& Mrles, A. A. (1946). Topley \& Wilson's Principles of Bacteriology and Immunity, 3rd ed. London: Arnold. pp. 575, 576.

Zollikofer, E. \& JANAIK, M. (1944). Zur serologischen Differenzierung des Streptococcus thermophilus. Schreiz. Z. Path. Bakt. 7, 65.

(Received 20 April 1948) 